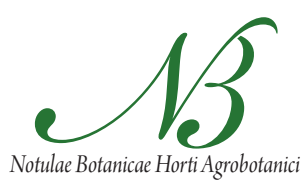

Cluj-Napoca

\title{
Seed and Saponin Production of Organic Quinoa (Chenopodium quinoa Willd.) for different Tillage and Fertilization
}

\author{
Dimitrios BILALIS ${ }^{1 *}$, Ioanna KAKABOUKI ${ }^{2}$, Anestis KARKANIS ${ }^{3}$, Ilias \\ TRAVLOS ${ }^{1}$, Vassilis TRIANTAFYLLIDIS ${ }^{2}$, Dimitra HELA² \\ ${ }^{1}$ Agricultural University of Athens, Laboratory of Crop Production, Iera Odos 75, 11855 \\ Athens, Greece; bilalisdimitrios@yahoo.gr (*corresponding author) \\ ${ }^{2}$ University of West Greece, Department of Business Administration of Food and Agricultural Enterprises, Seferi 2, 30100, Agrinio, Greece \\ ${ }^{3}$ University of Thessaly, Department of Agriculture Crop Production and Rural Environment, Fytokou Str, 38466, N. Ionia, Magnisia, Greece
}

\begin{abstract}
Field experiment was conducted to determine the effects of tillage systems and fertilization on growth, yield and quality of quinoa crop (Chenopodium quinoa Willd.). The experiment was laid out in a split-plot design with four replicates, two main plots [conventional tillage (CT) and minimum tillage (MT)] and three sub-plots (fertilization treatments: control, cow manure and compost). The soil porosity (45.5-49.75\%) and total nitrogen (0.144-0.173\%) were higher in soils subjected to MT system than under CT. In soil porosity, an interaction between fertilization and tillage system was found. The highest leaf area index (4.47-5.03), dry weight (8650-9290 kg $\left.\mathrm{ha}^{-1}\right)$ and root density $\left(1.03-1.21 \mathrm{~cm} \mathrm{~cm}^{-3}\right)$ were also found in MT. Moreover, there were significant differences between the organic fertilization treatments concerning the LAI, dry weight and root density. The highest seed yield $\left(2485-2643 \mathrm{~kg} \mathrm{ha}^{-1}\right)$ and saponin content (0.42-0.45\%) were found in cow manure and compost treatments. Also, the highest saponin yield $\left(7.70-12.05 \mathrm{~kg}^{-1}\right)$ was found in the MT system. Saponin yield had positive and significant correlation with total $\mathrm{N}(r=0.866, p<0.001)$. In quinoa measurements, an interaction between fertilization and tillage system was not found. The present results indicated that MT and organic fertilization increase saponin yield of quinoa.
\end{abstract}

Keywords: fertilization, quinoa, no-tillage, organic, saponin, tillage system

\section{Introduction}

Quinoa (Chenopodium quinoa Willd.) is a pseudocereal that has been cultivated in Andean region for thousands of years (Bhargava et al., 2006). Quinoa has been called a pseudo-cereal for botanical reasons but also, because of its unusual composition and exceptional balance between oil, protein and fat. Quinoa is an excellent example of 'functional food' that aims at lowering the risk of various diseases (Vega-Gálvez et al., 2010). It has remarkable nutritional properties; not only its protein content (15\%) but also its great amino acid balance. It is an important source of minerals and vitamins, and it has been found to contain compounds like polyphenols, phytosterols, and flavonoids with possible nutraceutical benefits (Abugoch James, 2009). Moreover, quinoa plants contain saponins (Kuljanabhagavad and Wink, 2009). Saponins in quinoa are basically glycosidic triterpenoids with glucose constitution about $80 \%$ of the weight (Bhargava et al., 2006).

Quinoa has a significant, worldwide potential as a new cultivated crop species and as an imported commodity from South America (Jacobsen, 2003). Little information is currently available on quinoa crop production. Schulte auf'm Erley et al. (2005) reported that quinoa responded strongly to nitrogen fertilization, Berti et al. (2000) also found that the highest quinoa yields were obtained with the highest nitrogen rate $\left(225 \mathrm{~kg} \mathrm{ha}^{-1}\right)$. Moreover, Eisa et al. (2012) reported that quinoa is a promising salt-tolerant plant and it can be grown productively under low to moderate saline conditions.

Tillage systems affect soil physical properties differently, because of their varied tillage intensities, which in turn affect infiltration characteristics (Bhattacharyya et al., 2008). Under minimum tillage (reduced tillage) agriculture, the soil is not inverted and mixed with the crop residues and this seems to profoundly impact many soil properties particularly in the upper soil layer (D'Haene et al., 2008). Daraghmeh et al. (2009) reported that reduced tillage improved soil structure through a combination of increased soil organic matter, reduced soil bulk density and increased proportion of larger aggregates. Alvarez and Steinbach (2009) also observed that aggregate stability and water infiltration rate were higher in soils subjected to limited tillage systems than under plow tillage.

Data obtained by other researchers (Bhattacharyya et al., 2008; Bilalis et al., 2010; Cantero-Martinez et al., 2007; Efhimiadou et al., 2009; Quattara et al., 2008) clearly demonstrate the beneficial effects of reduced till- 
age and organic fertilization on the yields of crops (flax, maize, cotton). There were no information about the effects of tillage systems and organic fertilization on quinoa growth and yield. Therefore, the aim of this study was to determine the effects of tillage system and organic fertilization on growth and saponin content yield of quinoa crop. Limited data are available regarding the performance of quinoa growth in an organic cropping system.

\section{Material and methods}

\section{Experimental design}

A quinoa crop (Chenopodium quinoa Willd.) was established in the area of Agrinio (western Greece, Lat: $38^{\circ} 35^{\prime}$, Long: $21^{\circ} 25^{\prime}$ ) in 2010 and 2011 . The soil was a clay loam $(24.9 \%$ clay, $61.2 \%$ silt, and $13.9 \%$ sand) with $\mathrm{pH}$ 7.4 , organic matter $1.45 \%$, EC $0.63 \mathrm{mS} \mathrm{cm}^{-1}, 0.152 \%$ total nitrogen and a sufficient supply of phosphorus (P Olsen: $175 \mathrm{mg} \mathrm{kg}^{-1}$ soil) and potassium (632 $\mathrm{mg} \mathrm{kg}^{-1}$ soil). Some meteorological data of the experimental sites are presented in Fig. 1. The sites were managed according to organic agriculture guidelines (EC 834/2007). The experiments were set up on an area of $600 \mathrm{~m}^{2}$ according to the split-plot design with four replicates, two main plots (conventional tillage: CT, moldboard plowing at $20-25 \mathrm{~cm}$, followed by one rotary hoeing at $5-10 \mathrm{~cm}$; minimum tillage: MT, chiseling at $20 \mathrm{~cm}$ depth followed by one rotary hoeing at $5-10 \mathrm{~cm}$; no-tillage) and three sub-plots (fertilization treatments: control, cow manure $\left(2000 \mathrm{~kg} \mathrm{ha}^{-1}, 1.24 \% \mathrm{~N}\right)$ and seaweed compost $\left(250 \mathrm{~kg} \mathrm{ha}^{-1}\right.$, with $\left.8 \% \mathrm{~N}\right)$. The main plot size was $150 \mathrm{~m}^{2}$. The crop was cultivated before quinoa becomes wheat. Quinoa was sown by hand in rows $30 \mathrm{~cm}$ apart, at a depth of $3 \mathrm{~cm}$. Quinoa was sown on $10^{\text {th }}$ of May 2010 and $15^{\text {th }}$ of May 2011 at a rate of $10 \mathrm{~kg} \mathrm{ha}^{-1}$. Finally, weeds were controlled by hand 30 days after sowing.

\section{Sampling, measurements and methods}

Total porosity of the soil was determined by $1-\mathrm{Db} /$ $\mathrm{Dp}$, where $\mathrm{Dp}$ is the particle density $\left(2.5 \mathrm{~g} \mathrm{~cm}^{-3}\right)$ and $\mathrm{Db}$ is the soil bulk density. Soil bulk density was determined for each plot by taking undisturbed soil cores with $100 \mathrm{~cm}^{3}$ cylinders from a depth of $0-10 \mathrm{~cm}$. Three samples of 100 $\mathrm{cm}^{3}$ per plot were taken ( 90 days after sowing (DAS). The undisturbed samples were finally oven dried at $100^{\circ} \mathrm{C}$ for $24 \mathrm{~h}$ to obtain soil dry mass and the soil bulk density was calculated as follow: $\mathrm{Db}=$ dry mass $(\mathrm{g}) / 100 \mathrm{~cm}^{3}$. The total nitrogen was determined by the Kjeldahl method (Bremner, 1960) using a Buchi 316 device in order to combust and extract the soil samples.

For the computation of dry weight and LAI (75 DAS), 10 plants were randomly selected in each plot. The dry weight was determined after drying for $72 \mathrm{~h}$ at $70^{\circ} \mathrm{C}$. Leaf area was measured using an automatic leaf area meter (Delta-T Devices Ltd). Root samples were collected 75 DAS and from the $0-25 \mathrm{~cm}$ layer by using a cylindrical auger $(25 \mathrm{~cm}$ length, $10 \mathrm{~cm}$ diameter $)$ at the midpoint between successive plants within a row. For each sample, roots were separated from soil after being in water + $\left(\mathrm{NaPO}_{3}\right)_{6}+\mathrm{Na}_{2} \mathrm{CO}_{3}$ for $24 \mathrm{~h}$. For the determination of the root density, the root samples were placed on a high-resolution scanner using DT software (Delta-T Scan version 2.04; Delta-T Devices Ltd, Burrwell, Cambridge, UK).

The quinoa seed yield also was determined by manually harvesting the plants of the two central rows of each plot on $15^{\text {th }}$ of September. Saponin content in the seeds was estimated using reverse phase HPLC based on the protocol described by San Martın and Briones (2000). Seeds for extraction $(30 \mathrm{~g})$ were thoroughly grounded and then extracted with water at $60^{\circ} \mathrm{C}$ for $3 \mathrm{~h}$. The ratio of water to seeds was 15 to 1 (by weight). The extract was centrifuged and the supernatant filtered (pore size $0.45 \mathrm{~lm}$ ) and then analysed by RP-HPLC (Martinez et al., 2009).

\section{Statistical analysis}

For calculating analysis of variance and comparisons of means, Statistica software (StatSoft Inc, Tulsa, OK, USA) was used. The $L S D$ test was used to detect and separate the mean treatment differences. Correlation analyses were used to describe the relationships between growth parameters and yield components. All comparisons were made at the $5 \%$ level of significance.

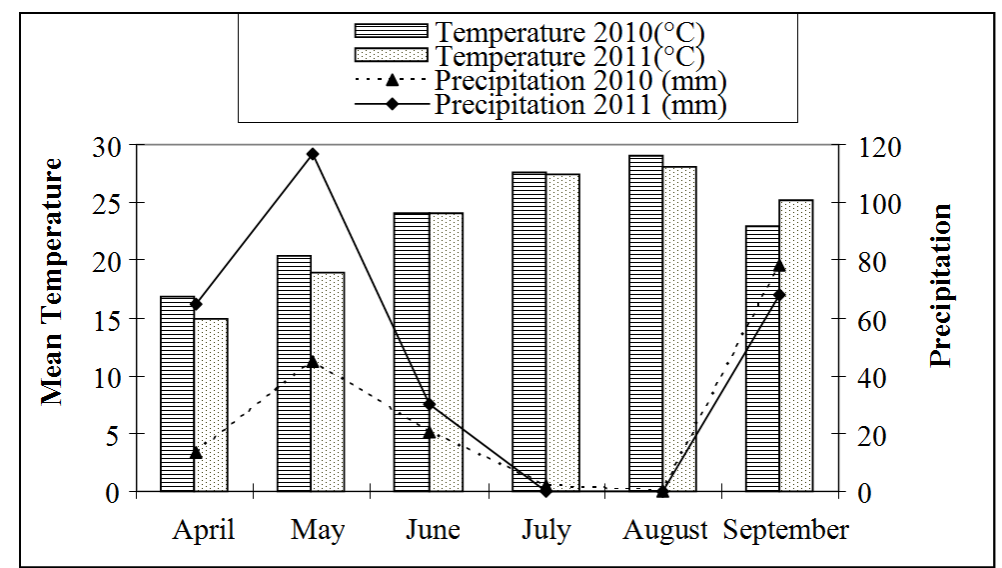

Fig. 1. Meteorological data (temperature: ${ }^{\circ} \mathrm{C}$ and precipitation: $\mathrm{mm}$ ) for the experimental sites during the experimental periods (April-September) 
44

\section{Results and discussion}

\section{Soil properties}

The lowest soil porosity and total $\mathrm{N}$ were found under CT (Tab. 1). In soil porosity, an interaction between fertilization and tillage system was found. There were statistically significant differences between MT and CT systems. Moreover, there were significant differences between the organic fertilization treatments concerning the soil porosity and total $\mathrm{N}$.

The adoption of conservation tillage practices that include NT or minimum tillage (MT) has been shown to lead to soil improvement: organic matter, porosity, bulk density, aggregate stability and water infiltration rate (Alvarez and Steinbach, 2009; Bilalis et al., 2011; Daraghmeh et al., 2009). In a previous study, it was shown that the soil organic matter and total nitrogen were higher in soils subjected to conservation tillage systems (minimum and no-tillage) than to conventional tillage (Bilalis et al. 2010; Wang et al. 2012).

\section{Quinoa growth and yield}

Concerning the root density, there were significant differences between CT and MT systems (Tab. 2). MunozRomero et al. (2010) found that the wheat root length was greater under NT than under CT for the most growth stages and depths. Also, there were significant differences in root growth between fertilization treatments. The lowest root diameter was found under control treatment. Root density had positive and significant correlation with soil porosity and total $\mathrm{N}(r=0.573, p<0.01$, and $r=0.820$, $p<0.001$, respectively). Moreover, the lowest LAI (Tab. 2) and dry weight (Tab. 3) were found under MT. The highest LAI and dry weight was found under cow manure treatment. Data obtained by other researchers (Bilalis et al., 2010; Efthimiadou et al., 2009) clearly demonstrate the

Tab. 1. Effects of tillage system (conventional tillage: CT, minimum tillage: MT) and organic fertilization (control, cow manure and compost) on porosity (\%) and nitrogen (\%) of quinoa

\begin{tabular}{|c|c|c|c|c|c|c|}
\hline \multirow{2}{*}{ Tillage system } & \multicolumn{6}{|c|}{ Organic fertilization } \\
\hline & Control & Cow manure & Compost & Control & Cow manure & Compost \\
\hline Experiment 2010 & \multicolumn{3}{|c|}{ Porosity\% } & \multicolumn{3}{|c|}{$\mathrm{N} \%$} \\
\hline CT & 39.25 & 42.50 & 39.75 & 0.121 & 0.141 & 0.136 \\
\hline MT & 44.00 & 46.75 & 47.50 & 0.144 & 0.164 & 0.158 \\
\hline $\mathrm{F}_{\text {tillage }}$ & \multicolumn{3}{|c|}{$90.21^{* *}\left(\mathrm{LSD}_{5 \%}=1.87\right)$} & \multicolumn{3}{|c|}{$10.74^{*}\left(\mathrm{LSD}_{5 \%}=0.013\right)$} \\
\hline $\mathrm{F}_{\text {fertilization }}$ & \multicolumn{3}{|c|}{$17.72^{* * *}\left(\operatorname{LSD}_{5 \%}=1.44\right)$} & \multicolumn{3}{|c|}{$20.89^{* *}\left(\operatorname{LSD}_{5 \%}=0.014\right)$} \\
\hline $\mathrm{F}_{\text {trillagexferrilizarion }}$ & \multicolumn{3}{|c|}{13.24} & \multicolumn{3}{|c|}{$0.76^{\mathrm{ns}}$} \\
\hline Experiment 2011 & \multicolumn{3}{|c|}{ Porosity\% } & \multicolumn{3}{|c|}{$\mathrm{N} \%$} \\
\hline $\mathrm{CT}$ & 40 & 43.25 & 40.75 & 0.137 & 0.156 & 0.149 \\
\hline MT & 45.50 & 48 & 49.75 & 0.156 & 0.173 & 0.164 \\
\hline $\mathrm{F}_{\text {tillage }}$ & \multicolumn{3}{|c|}{$87.60^{* *}\left(\mathrm{LSD}_{5 \%}=2.18\right)$} & \multicolumn{3}{|c|}{$10.32^{*}\left(\mathrm{LSD}_{5 \%}=0.016\right)$} \\
\hline $\mathrm{F}_{\text {ferrilizzation }}$ & \multicolumn{3}{|c|}{$19.01^{* * *}\left(\operatorname{LSD}_{5 \circ}=1.10\right)$} & \multicolumn{3}{|c|}{$22.51^{* *}\left(\mathrm{LSD}_{5^{\circ}}=0.005\right)$} \\
\hline $\mathrm{F}_{\text {rillarevfererilizarion }}$ & \multicolumn{3}{|c|}{$10.01^{3 \%}$} & \multicolumn{3}{|c|}{$0.44^{\mathrm{ns}}$} \\
\hline
\end{tabular}

F-test ratios are from ANOVA. Significant at ${ }^{*} \mathrm{p}=0.05,{ }^{* *} \mathrm{p}=0.01,{ }^{* * *} \mathrm{p}=0.001$, ns: not significant. The $\mathrm{LSD}(\mathrm{p}=0.05)$ for tillage systems and organic fertilization are also shown

Tab. 2. Effects of tillage system (conventional tillage: CT, minimum tillage: MT) and organic fertilization (control, cow manure and compost) on root density $\left(\mathrm{cm} \mathrm{cm}^{-3}\right)$ and leaf area index (LAI) of quinoa

\begin{tabular}{|c|c|c|c|c|c|c|}
\hline \multirow{2}{*}{ Tillage system } & \multicolumn{6}{|c|}{ Organic fertilization } \\
\hline & Control & Cow manure & Compost & Control & Cow manure & Compost \\
\hline Experiment 2010 & \multicolumn{3}{|c|}{ Root density } & \multicolumn{3}{|c|}{ LAI } \\
\hline CT & 0.88 & 1.04 & 0.99 & 4.08 & 4.45 & 4.36 \\
\hline MT & 1.03 & 1.24 & 1.16 & 4.47 & 4.89 & 4.66 \\
\hline $\mathrm{F}_{\text {tillage }}$ & \multicolumn{3}{|c|}{$92.46^{* *}\left(\mathrm{LSD}_{5 \%}=0.042\right)$} & \multicolumn{3}{|c|}{$10.39^{\circ}\left(\mathrm{LSD}_{5 \%}=0.14\right)$} \\
\hline $\mathrm{F}_{\text {fertilization }}$ & \multicolumn{3}{|c|}{$45.31^{* * *}\left(\mathrm{LSD}_{5 \%}=0.043\right)$} & \multicolumn{3}{|c|}{$39.02^{* * *}\left(\mathrm{LSD}_{5 \%}=0.08\right)$} \\
\hline $\mathrm{F}_{\text {rillharexferrilization }}$ & \multicolumn{3}{|c|}{$1.78^{\text {ns }}$} & \multicolumn{3}{|c|}{$2.02^{\mathrm{ns}}$} \\
\hline Experiment 2011 & \multicolumn{3}{|c|}{ Root density } & \multicolumn{3}{|c|}{ LAI } \\
\hline $\mathrm{CT}$ & 0.91 & 1.10 & 1.05 & 4.35 & 4.70 & 4.60 \\
\hline MT & 1.07 & 1.21 & 1.14 & 4.58 & 5.03 & 4.75 \\
\hline $\mathrm{F}_{\text {tillage }}$ & \multicolumn{3}{|c|}{$94.23^{* *}\left(\mathrm{LSD}_{5 \%}=0.039\right)$} & \multicolumn{3}{|c|}{$6.83^{\mathrm{ns}}\left(\mathrm{LSD}_{5 \%}=0.28\right)$} \\
\hline $\mathrm{F}_{\text {ferrilization }}$ & \multicolumn{3}{|c|}{$47.00^{* * *}\left(\mathrm{LSD}_{5 \%}=0.037\right)$} & \multicolumn{3}{|c|}{$35.49^{* * *}\left(\mathrm{LSD}_{5 \%}=0.10\right)$} \\
\hline $\mathrm{F}_{\text {tillarexfercilization }}$ & \multicolumn{3}{|c|}{$2.26^{\mathrm{ns}}$} & \multicolumn{3}{|c|}{$1.71^{\mathrm{ns}}$} \\
\hline
\end{tabular}

F-test ratios are from ANOVA. Significant at ${ }^{*} \mathrm{p}=0.05,{ }^{* *} \mathrm{p}=0.01,{ }^{* * *} \mathrm{p}=0.001$, ns: not significant. The LSD ( $\left.\mathrm{p}=0.05\right)$ for tillage systems and organic fertilization are also shown 
beneficial effects of manure and composts on the growth and yields of crops (flax maize). Dry weight and LAI had positive and significant correlation with root density $(r=0.850, p<0.001$, and $r=0.869, p<0.001$, respectively).

Yield was influenced by both tillage system and fertilization (Tab. 3). The highest grain yields were found under the MT system. Data obtained by other researchers demonstrate the beneficial effects of reduced tillage on the crops yields. The highest seed yield $\left(1761 \mathrm{~kg} \mathrm{ha}^{-1}\right)$ and oil yield $\left(670 \mathrm{~kg} \mathrm{ha}^{-1}\right)$ of flax (Linum usitatissimum L.) were found under minimum tillage (Bilalis et al., 2010). In addition, soybean (Glycine max L. Merr.) yield was not affected by tillage system (Alvarez and Steinbach, 2009). The lowest seed yield $\left(2415 \mathrm{~kg} \mathrm{ha}^{-1}\right)$ was found under the NT system with control, while the highest $\left(2613 \mathrm{~kg} \mathrm{ha}^{-1}\right)$ was found in cow manure plots. Quinoa responds well to nitrogen fertilizers. Berti etal.(2000) found that the highest quinoa yields were obtained with the highest nitrogen rate (225 $\left.\mathrm{kg} \mathrm{ha}^{-1}\right)$. Moreover, Schulte auf'm Erley et al. (2005) reported that quinoa yielded between 1790 and $3495 \mathrm{~kg}$ grain $\mathrm{ha}^{-1}$ and responded strongly to $\mathrm{N}$ fertilization. Seed yield had positive and significant correlation with total $\mathrm{N}$, root density and LAI $(r=0.866, p<0.001, r=0.759$, $p<0.001$ and $r=0.752, p<0.001$, respectively).

\section{Saponin content and yield}

The assessment of quinoa saponin content is of a great importance for the industry. There are not data available regarding the performance of quinoa growth under limited tillage systems and organic fertilization. The present results indicated that there were no significant differences in saponin content between tillage systems (Tab. 4). Moreover, there were significant differences in saponin content between fertilization treatments. The lowest saponin content was found under control treatment $(0.30-0.35 \%)$. Martinez et al. (2009) reported higher saponin content in the seeds (1.2\%).

Tab. 3. Effects of tillage system (conventional tillage: CT, minimum tillage: MT) and organic fertilization (control, cow manure and compost) on dry weight and yield $\left(\mathrm{kg} \mathrm{ha}^{-1}\right)$ of quinoa

\begin{tabular}{|c|c|c|c|c|c|c|}
\hline \multirow{2}{*}{ Tillage system } & \multicolumn{6}{|c|}{ Organic fertilization } \\
\hline & Control & Cow manure & Compost & Control & Cow manure & Compost \\
\hline Experiment 2010 & \multicolumn{3}{|c|}{ Dry weight } & \multicolumn{3}{|c|}{ Yield } \\
\hline CT & 7947 & 8320 & 8158 & 2175 & 2450 & 2374 \\
\hline MT & 8650 & 9054 & 8962 & 2325 & 2578 & 2485 \\
\hline $\mathrm{F}_{\text {tillage }}$ & \multicolumn{3}{|c|}{$21.22^{*}\left(\mathrm{LSD}_{5 \%}=346\right)$} & \multicolumn{3}{|c|}{$17.83^{*}\left(\mathrm{LSD}_{5 \%}=97.26\right)$} \\
\hline $\mathrm{F}_{\text {fertilization }}$ & \multicolumn{3}{|c|}{$23.48^{* \prime}\left(\mathrm{LSD}_{5 \%}=97\right)$} & \multicolumn{3}{|c|}{$39.52^{* * *}\left(\mathrm{LSD}_{5 \%}=50.69\right)$} \\
\hline $\mathrm{F}_{\text {tillagexferrilizarion }}$ & \multicolumn{3}{|c|}{$0.14^{\mathrm{ns}}$} & \multicolumn{3}{|c|}{$0.48^{\mathrm{ns}}$} \\
\hline Experiment 2011 & \multicolumn{3}{|c|}{ Dry weight } & \multicolumn{3}{|c|}{ Yield } \\
\hline $\mathrm{CT}$ & 8495 & 8800 & 8647 & 2315 & 2525 & 2413 \\
\hline MT & 8970 & 9290 & 9138 & 2415 & 2643 & 2538 \\
\hline $\mathrm{F}_{\text {tillage }}$ & \multicolumn{3}{|c|}{$23.65^{*}\left(\mathrm{LSD}_{5 \%}=317\right)$} & \multicolumn{3}{|c|}{$12.11^{*}\left(\operatorname{LSD}_{5 \%}=104.42\right)$} \\
\hline$F_{\text {fertilization }}$ & \multicolumn{3}{|c|}{$19.16^{\circ}\left(\mathrm{LSD}_{5 \%}=109\right)$} & \multicolumn{3}{|c|}{$35.67^{* * *}\left(\mathrm{LSD}_{5 \%}=56.43\right)$} \\
\hline $\mathrm{F}_{\text {rillagerfecrilizarion }}$ & \multicolumn{3}{|c|}{$0.01^{\mathrm{ns}}$} & \multicolumn{3}{|c|}{$0.12^{\mathrm{ns}}$} \\
\hline
\end{tabular}

F-test ratios are from ANOVA. Significant at ${ }^{*} \mathrm{p}=0.05,{ }^{* *} \mathrm{p}=0.01,{ }^{* * *} \mathrm{p}=0.001$, ns: not significant. The $\operatorname{LSD}(\mathrm{p}=0.05)$ for tillage systems and organic fertilization are also shown

Tab. 4. Effects of tillage system (conventional tillage: CT, minimum tillage: MT) and organic fertilization (control, cow manure and compost) on saponin content $(\%)$ and saponin yield $\left(\mathrm{kg} \mathrm{ha}^{-1}\right)$ of quinoa

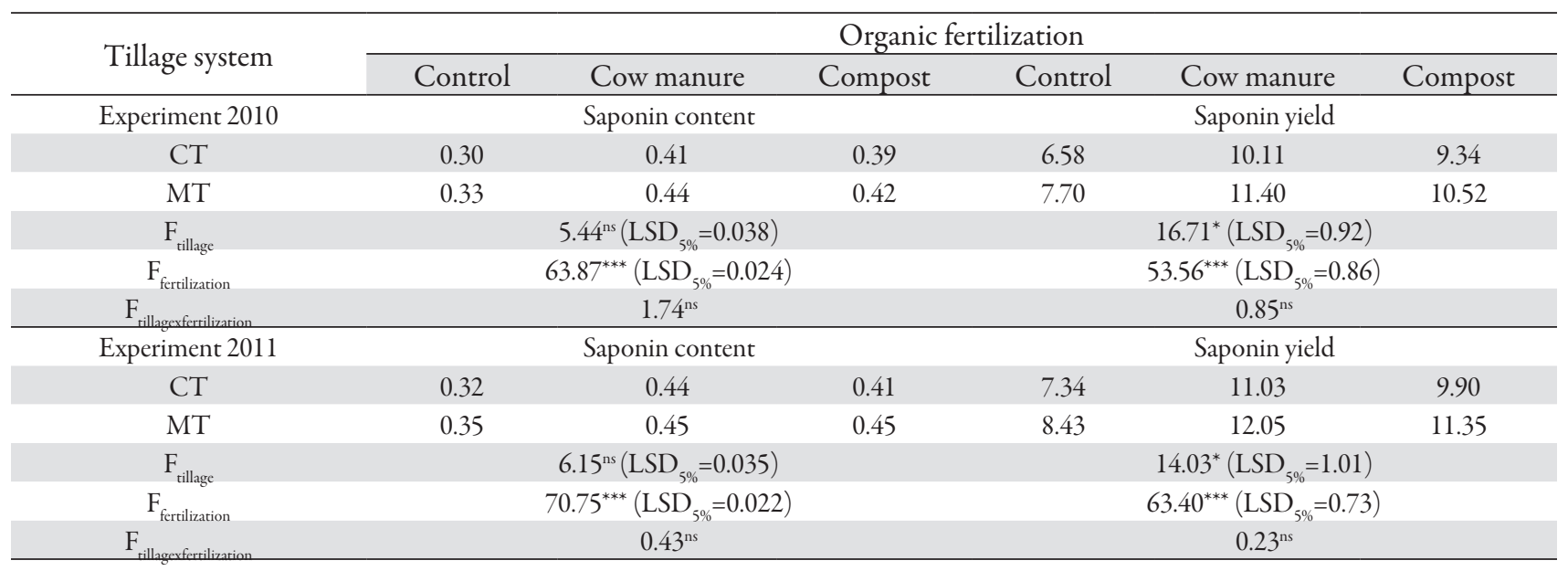

F-test ratios are from ANOVA. Significant at ${ }^{*} \mathrm{p}=0.05,{ }^{* * *} \mathrm{p}=0.001$, ns: not significant. The LSD ( $\left.\mathrm{p}=0.05\right)$ for tillage systems and organic fertilization are also shown 
46

The saponin yield was influenced by both tillage system and fertilization (Tab. 4). The highest saponin yield was found under the MT system. The lowest saponin yield $\left(8.43 \mathrm{~kg} \mathrm{ha}^{-1}\right.$ and $7.70 \mathrm{~kg} \mathrm{ha}^{-1}$, for 2011 and 2010, respectively) was found under the NT system with control, while the highest $\left(12.035 \mathrm{~kg} \mathrm{ha}^{-1}\right.$ and $11.40 \mathrm{~kg} \mathrm{ha}^{-1}$, for 2011 and 2010, respectively) was found in cow manure plots. Saponin yield had positive and significant correlation with total N, root density and LAI $(r=0.860, p<0.001$, $r=0.852, p<0.001$ and $r=0.807, p<0.001$, respectively). Finally, in quinoa measurements, an interaction between fertilization and tillage system was not found.

\section{Conclusions}

The present results indicate that the high saponin content of quinoa was produced under the minimum tillage. Moreover, it was found that quinoa which was cultivated under minimum tillage had higher yield. There were significant differences between the fertilization treatments concerning the seed yield and saponin yield as well. The highest saponin content and yield were found in cow manure and compost treatments. Finally, organic fertilization and minimum tillage improved the soil quality.

\section{References}

Abugoch James LE (2009). Quinoa (Chenopodium quinoa Willd.): composition, chemistry, nutritional, and functional properties. Adv Food Nutr Res 58:1-31.

Alvarez R, Steinbach HS (2009). A review of the effects of tillage systems on some soil physical properties, water content, nitrate availability and crops yield in Argentine Pampas. Soil Tillage Res 104:1-15.

Berti M, Wilckens R, Hevia F, Serri H, Vidal I, Mendez C (2000). Fertilizacion nitrogenada en quinoa (Chenopodium quinoa Willd.). Ciencia Investigacion Agraria 27:81-90.

Bhargava A, Shukla S, Ohri D (2006). Chenopodium quinoaAn Indian perspective. Ind Crops Prod 23:73-87.

Bhattacharyya R, Kundu S, Pandey SC, Singh KP, Gupta HS (2008). Tillage and irrigation effects on crop yields and soil properties under the rice-wheat system in the Indian Himalayas. Agric Water Manage 95:993-1002.

Bilalis D, Karkanis A, Patsiali S, Agrogianni M, Konstantas A, Triantafyllidis V (2011). Performance of Wheat Varieties (Triticum aestivum L.) under Conservation Tillage Practices in Organic Agriculture. Not Bot Horti Agrobo 39:28-33.

Bilalis DJ, Karkanis A, Papastylianoum P, Patsiali S, Athanasopoulou M, Barla G, Kakabouki I (2010). Response of organic linseed (Linum usitatissimum L.) to the combination of tillage systems, (minimum, conventional and no-tillage) and fertilization practices: Seed and oil yield production. Aust J Crop Sci 4:700-705.

Bremner JM (1960). Determination of nitrogen in soil by Kjedahl method. J Agric Sci 55:11-33.

Cantero-Martinez C, Angas P, Lampurlanes J (2007). Longterm yield and water-use efficiency under various tillage systems in Mediterranean rain-fed conditions. Ann Appl Bot 150:293-305.

Daraghmeh OA, Jensen JR, Petersen CT (2009). Soil structure stability under conventional and reduced tillage in a sandy loam. Geoderma 150:64-71.

D'Haene K, VermangJ, Cornelis WM, Leroy BLM, Schiettecatte W, De Neve S, Gabriels D, Hofman G (2008). Reduced tillage effects on physical properties of silt loam soils growing root crops. Soil Tillage Res 99:279-290.

EC 834 (2007). Council Regulation (EC) No 834/2007 of 28 June 2007 on organic production and labeling of organic products and repealing Regulation (EEC) No 2092/91. The Council of the European Union. Off J Eur Union L189/1$189 / 23$

Efthimiadou A, Bilalis D, Karkanis A, Froud-Williams B, Eleftherochorinos I (2009). Effects of cultural system (organic and conventional) on growth, photosynthesis and yield components of sweet corn (Zea mays L.), under semiarid environment. Not Bot Horti Agrobo 37:105-111.

Eisa S, Hussin S, Geissler N, Koyro HW (2012). Effect of NaCl salinity on water relations, photosynthesis and chemical composition of Quinoa (Chenopodium quinoa Willd.) as a potential cash crop halophyte. Aust J Crop Sci 6:357-368.

Jacobsen SE (2003). The Worldwide Potential for Quinoa (Chenopodium quinoa Willd.). Food Rev Int 19:167-177.

Kuljanabhagavad T, Wink M (2009). Biological activities and chemistry of saponins from Chenopodium quinoa Willd. Phytochem Rev 8:473-490.

Martinez EA, Veas E, Jorquera C, San Martın R, Jara P (2009). Re-Introduction of quinoa into Arid Chile: Cultivation of two lowland races under extremely low irrigation. J Agron Crop Sci 195:1-10

Munoz-Romero V, Benitez-Vega J, Lopez-Bellido L, LopezBellido RJ (2010). Monitoring wheat root development in a rainfed vertisol: Tillage effect. Eur J Agron 33:182-187.

Quattara K, Quattara B, Nyberg G, Sedogo MP, Malmer A (2008). Effects of ploughing frequency and compost on soil aggregate stability in a cotton-maize (Gossypium hirsutumZea mays) rotation in Burkina Faso. Soil Use Manag 24:1928.

San Martın R, Briones R (2000). Quality control of commercial quillay (Quillaja saponaria Molina) extracts by reverse phase HPLC. J Sci Food Agric 80:2063-2068.

Schulte-auf'm-Erley G, Kaul HP, Kruse M, Aufhammer W (2005). Yield and nitrogen utilization efficiency of the pseudocereals amaranth, quinoa and buckwheat under differing nitrogen fertilization. Eur J Agron 22:95-100.

Vega-Gálvez A, Miranda M, Vergara J, Uribe E, Puente L, MartínezEA (2010).Nutrition facts and functional potential of quinoa (Chenopodium quinoa Willd.), an ancient Andean grain: a review. J Sci Food Agric 90:2541-2547.

Wang JJ, Lii XY, Zhu AN, Zhang XK, Zhang HW, Liang WJ (2012). Effect of tillage and residue management on soil microbial communities in North China. Plant Soil Environ 58:28-33. 